УДК 343.35

https://doi.org/10.32689/2708-7530-2020-1(1)-76-85

Семенова Юлія Миколаївна, аспірант Національного університету водного господарства та природокористування, 33000, м. Рівне, вул. Соборна, 11, тел.: 0362633 209, e-mail: julia.semenova12.12@gmail.com, https//orcid.org/0000-0002-5038-5215

Якимчук Аліна Юріївна, доктор економічних наук, професор кафедри державного управління, документознавства та інформаційної діяльності Національного університету водного господарства та природокористування, 33000, м. Рівне, вул. Соборна, 11, тел.: 0362633 209, e-mail: alinayakim@ukr.net, https//orcid.org/0000-0001-7805-6213

\title{
АСПЕКТИ ЕКОНОМІЧНОГО РЕГУЛЮВАННЯ ПРИРОДОКОРИСТУВАННЯ ПРОМИСЛОВИХ ПДПРИЕМСТВ В УКРАЇНІ У 2020 РОЦІ
}

Анотація. 2020-рік знаменується переходом України від Стратегії державної екологічної політики, що діяла у період до 2020 року, до Стратегії на період до 2030 року. Успадкувавши економічну структуру з переважаючою часткою ресурсоємних та енергоємних галузей, держава виявилася не готовою до екологізації економіки в цілому. Попередня програма розвитку покладала вирішити проблеми регулювання природокористування, недостатньої функціональності та сформованості інститутів громадянського суспільства та недотримання екологічного законодавства всіма суб'єктами природокористування загалом.

Нова стратегія поставила в пріоритет питання інтегрованого екологічного управління, екологізації економіки, міжсекторального партнерства, застосування принципів превентивності та досягнення екологічної сталості. Інструменти сталого виробництва, запроваджені на рівні галузей та підприємств, можуть бути застосовані для покращання екологічної дієвості та економічного стану підприємства, що, в свою чергу, дозволить проводити розрахунки інвестиційної діяльності для зниження обсягів природокористування, використання замкнутих циклів та екологізації вторинних процесів підприємств. Обгрунтовано, що ресурсоємні напрямки 
виробництва, характерні для України у попередні періоди, продовжують мати суттєвий вплив на навколишнє середовище в умовах ринкової економіки.

Саме екологізація таких процесів дає поштовх тенденції «зеленого офісу» як стандарту, який дає можливість оптимізувати витрати, досягти зменшення ресурсовикористання та розвивати екологічну свідомість на рівні окремих громад. Послідовна екологізація економіки 3 урахуванням сталості може функціонувати на кількох рівнях: макрорівні, галузевому та на рівні підприємств. Вважаємо, що досягнення глобальних цілей як екологізація економіки потребує впливу на функціональність напряму на макрорівні.

Ключові слова: екологізація, екологічна економіка, зелений офіс, стале виробництво.

Semenova Yuliya Mykolayivna, Post-Graduated Student of State Administration, Documentation and Information Activities Department, 33000, Rivne, str. Soborna, 11, phone number: 0362-62-31-65, e-mail: julia.semenova12.12@gmail.com, https//orcid.org/0000-0002-5038-5215

Yakymchuk Alina Yuriyivna, Doctor of Economic Sciences, professor of State Administration, Documentation and Information Activities Department, 33000, Rivne, str. Soborna, 11, phone number: 0362-62-31-65, e-mail: alinayakim@ukr.net, https//orcid.org/0000-0001-7805-6213

\section{ASPECTS OF ECONOMIC REGULATION OF NATURE USE OF INDUSTRIAL ENTERPRISES IN UKRAINE IN 2020}

Abstract. 2020 marks the transition of Ukraine from the Strategy of State Environmental Policy, which was in force until 2020, to the Strategy for the period until 2030. Having inherited an economic structure with a predominant share of resource-intensive and energy-intensive industries, the state was not ready to green the economy as a whole. The previous development program was aimed at solving the problems of nature management regulation, insufficient functionality and formation of civil society institutions and non-compliance with environmental legislation by all nature management entities in general.

The new strategy has prioritized the issues of integrated environmental management, greening of the economy, intersectoral partnership, application of the principles of prevention and achieving environmental sustainability. Sustainable production tools implemented at the level of industries and enterprises can be used to improve the environmental efficiency and economic condition of the enterprise, 
which, in turn, will calculate investment activities to reduce environmental use, use of closed cycles and greening of secondary processes. It is substantiated that resourceintensive directions of production, typical for Ukraine in previous periods, continue to have a significant impact on the environment in a market economy.

It is the greening of such processes that gives impetus to the trend of "green office" as a standard that allows you to optimize costs, reduce resource use and develop environmental awareness at the community level. Consistent greening of the economy, taking into account sustainability, can operate at several levels: macro, sectoral and enterprise. We believe that the achievement of global goals as the greening of the economy requires an impact on the functionality of the direction at the macro level.

Keywords: greening, ecological economy, green office, sustainable production.

Постановка проблеми. Вступ у дію Закону України «Про основні засади державної екологічної політики України на період до 2030 року», і відповідно Стратегії, суттєво оновленої у порівнянні 3 попередньою стратегією, формалізував нові напрямки державної політики у сфері природокористування у зв'язку з новими економічними, політичними та соціальними реаліями. Вплив на даний документ мали міжнародні угоди, у тому числі Паризька угода та Кіотський протокол, а також стратегї регіонального розвитку, спрямованої на підвищення продуктивності економіки регіонів, розвитку бізнес-середовища та покращання якості життя.

Теорія екологізації економіки стикнулася з тим, що зміни на шляху до екологічної сталості підприємств країни потребують регулювання глобальних процесів. Ресурсоємні напрямки виробництва, характерні для України у попередні періоди, продовжують мати суттєвий вплив на навколишнє середовище в умовах ринкової економіки.

Базові екологічні проблеми, окреслені у Стратегії до 2020 року, не вирішені і потребували системних змін для виконання Стратегії до 2030 року. Екологічні пріоритети на даний час підпорядковані економічній діяльності, ресурсоємність галузей знаходиться на високому рівні, переважання ресурсоємних та енергоємних галузей посилює деструктивний вплив на навколишнє природне середовище. Фінансування природоохоронних заходів на місцях відбувається за залишковим принципом, оскільки суспільне розуміння екологічних пріоритетів залишається на низькому рівні. Посилення відповідальності за порушення екологічного законодавства $є$ одностороннім засобом впливу на екологізацію економіки, тому екологічна сталість промислових підприємств може бути досягнута при одночасному задіянні 
інструментів організаційно-економічного механізму регулювання природокористування 3 одночасним запровадженням системи інтегрованого екологічного управління та вдосконаленням системи екологічної освіти.

Аналіз останніх досліджень і публікацій. Правову, економічну основи економічного регулювання екологічних процесів промислових підприємств досліджували науковці: Р. Г. Дубас, С.В. Берзіна, Г.С. Бузан, В.М. Вакараш, Т.В. Князькова, А.В. Ворфоломеєв, Ю.В. Гайдаєнко, Б.М. Кравченко, О.В. Ткач, О.А. Чайковський, О.П. Хохотва, М.М. Цибка, І.Л. Шилович. Науковці зосереджуються на питаннях сталої екологічності у контексті зеленої модернізації економіки.

Практична реалізація завдання вирішення питання екологізації економіки потребує комплексного дослідження дієвості інструментів екологізації та подальших наукових досліджень у даному напрямку.

Метою статті $\epsilon$ аналіз економічного регулювання природокористування промислових підприємств у контексті виконання Стратегії державної екологічної політики до 2020 року та у перспективі врахування Стратегії державної екологічної політики до 2030 року.

Виклад основного матеріалу. 31 січня 2020 року вступив в дію Закон України «Про основні засади (стратегію) державної екологічної політики України на період до 2030 року», покладений вживати термінові системні заходи для збереження довкілля і спрямування економічного розвитку держави до збалансованого природокористування [1].

3 метою забезпечення сталого розвитку природно-ресурсного потенціалу України сплановане запровадження інструментів сталого споживання і сталого виробництва. Попередня стратегія державної екологічної політики України покладалась на політику сталого виробництва i споживання відповідно до Йоганнесбурзького плану дій, що стосувався: атмосферного повітря, охорони водних ресурсів, охорони лісів, геологічного середовища та надр, а також напрямку біобезпеки $[1 ; 2]$. Інструменти сталого виробництва - це сукупність інструментів організаційно-економічного механізму діяльності підприємств, орієнтована на досягнення цілей сталого виробництва і сталості підприємства загалом, що базується на управлінні екологічними аспектами і орієнтується на впровадження ресурсозберігаючих технологій. Враховуючи переваги сталого виробництва, такі, як підвищення продуктивності та зростання якості для досягнення ринкової прийнятності, а також заощадження коштів, підприємство досягає екологічної ефективності та економічного зростання. Міжнародний досвід врахування інструментів сталого розвитку полягає у застосуванні стандартів ISO та ISO 14000, які охоплюють аспекти технологій, виробництва, 
систем управління та метрології. Розвиток стандартів даної системи продовжує напрям міжнародного співробітництва в екологічній сфері, що полягає в обміні досвідом реалізації національних програм використання природних ресурсів, виконання міждержавних програм і угод та заснування міжнародних органів для контролю виконання таких угод. Еволюція реалізації міжнародних відносин у сфері природокористування знаменується переходом від формалізації питань збереження та використання окремих природних ресурсів до глобальних стратегій досягнення економічної ефективності підприємств 3 урахуванням екологічної складової. Виникає поняття екологічної дієвості підприємств, що полягає у вимірних результатах управління екологічними аспектами організацій. Оцінювання екологічної дієвості $є$ інструментом сталого розвитку підприємства, що доповнює екологічний аудит. Відмінність у тому, що екологічний аудит є плановим заходом, а оцінювання екологічної дієвості відбувається постійно, і його показники є частиною стратегії підприємства. Порівняння показників дієвості у різні періоди дає підстави підприємству або організації:

- Виставити пріоритетність екологічних аспектів і встановити цілі згідно цих аспектів.

- Визначити тенденції, напряму пов’язані з екологічною дієвістю (у тому числі, зв'язок попиту та екологічної діяльності).

- Оцінити рівень дотримання правових вимог.

- Поліпшити ефективність та результативність.

1. Показники екологічної дієвості соціального вектору використовуються для демонстрації позитивних результатів компанії в соціальному напрямку внаслідок ефективного управління екологічних аспектів (екологічне навчання,

2. Показники екологічної дієвості для покращання економічного стану підприємства враховують розрахунки планової інвестиційної діяльності для зниження обсягів використання природних ресурсів.

3. Показники, які використовуються безпосередньо екологічної діяльності, стосуються покращання якості ресурсів та покращання життя населення.

Такі показники класифікують як прямі розрахунки та вимірювання, відносні розрахунки (обсяги забруднення у відношенні до одиниці виготовленої продукції), індексовані (показники забруднень звітного періоду у порівнянні 3 попереднім), агреговані (враховують скиди забруднюючих речовин комплексно по галузі), а також зважені, що враховують коефіцієнти, застосовані для регулювання якісних змін [3]. Кроки до сталого природокористування покладаються на економічні інструменти, такі, як: система державних дотацій 
та здешевлення кредитів і компенсації по кредитним ставкам за оновлення зношених основних фондів промислової інфраструктури. Імплементація європейських стандартів та екологічних норм запланована у період до 2025 року, а до 2030 року державною стратегією передбачено забезпечення ефективного партнерства між державою, суб’єктами господарювання та громадським сектором.

Однією 3 ключових проблем екологічного напряму $\epsilon$ переважання ресурсоємних галузей у загальній структурі економіки, що у поєднанні зі стратегією переходу до ринкових умов ведення господарства, викликає стабільний негативний вплив на довкілля. Стратегією розвитку до 2030 року передбачено запровадження в Україні системи зелених закупівель, а також ряд кроків до усунення прямої залежності економічного зростання від збільшення природокористування та від збільшення обсягів забруднення навколишнього середовища.

На даному етапі для України властиві дві форми взаємодії суспільства та природи: економічна та екологічна, тому поєднання цих форм є глобальним системним завданням. Якщо екологічна форма полягає в охороні навколишнього природного середовища для збереження людини та $\dddot{11}$ середовища існування, то економічна форма полягає напряму у споживанні природних ресурсів, що викликає природній супротив у вигляді виснаження ресурсів та руйнування природного середовища [3; 4]. Економічне регулювання ринку полягає у неефективності ринкової системи при використанні ресурсів зі зниженою оцінкою, безоплатних ресурсів або використання, яке знаходиться поза межами контролю. Використання підприємствами безоплатних ресурсів та ресурсів із заниженою вартістю не відображається на внутрішніх затратах такого підприємства, проте збільшує суспільні екстерн альні витрати. 3 такої позиції регулювання стає критично необхідним на рівні, коли порушена сталість рівняння, за яким граничні витрати зменшення забруднення для підприємства дорівнюють граничному збитку, спричиненому забрудненням, $\mathrm{i}$ відповідає теорії економічної ефективності, при якій підприємство компенсує економічний збиток, нанесений екологічною діяльністю (бездіяльністю) підприємства.

Порівнюючи Стратегію розвитку до 2020 року і актуальну наразі Стратегію до 2030 року [1; 2], зауважимо, що попередня програма одним 3 пріоритетів враховувала завдання підвищення рівня екологічної безпеки, що планувалося реалізувати низкою заходів, пов'язаних в першу чергу 3 міжнародними ініціативами у сфері захисту природного середовища. Відповідно до Йоханнесбурзького плану дій постали завдання запровадити комплексний 
підхід до проведення оцінки ризиків (до 2015 року) та до запобігання наслідків стихійних лих. Відповідно до Кіотського протоколу було регламентовано завдання забезпечити скорочення викидів парникових газів та поступово збільшити обсяги використання джерел енергії 3 низьким рівнем викидів двоокису вуглецю. Нераціональне та виснажливе використання природних ресурсів визначено у Законі України «Про основи національної безпеки України» № 964-IV від 19.06.2003p (редакція від 05.03.2015.) як загрозу національній безпеці та національним інтересам України в екологічній сфері.

У Стратегії до 2030 року враховане питання відновлення та збереження навколишнього природного середовища Донбасу. Логічно, що фактор військово-політичної нестабільності був врахований для удосконалення попередньої Стратегії і став ключовим, на рівні з напрямками інтегрованого управління водними ресурсами, сталого розвитку усіх секторів природокористування, а також розвитку зеленої економіки.

Отже, зважаючи на стратегію об'єднання екологічного і економічного напрямів, приходимо до розуміння зеленої економіки як до стану залежності економіки від природного середовища і приналежності економіки до даної системи. Похідним напрямом зеленої економіки є концепція «зеленого офісу» як сукупності мотиваційних, технічних та освітніх заходів, покладених на підвищення корпоративної культури компаній та їх членів 3 акцентом на зниження навантаження на навколишнє середовище. Стандарт «зелений офіс» регламентує критерії екологічної результативності, які визначають енергоефективність підприємства, раціональність використання природних та матеріальних ресурсів, раціональне поводження 3 відходами і забезпечення функціонування системи «зелених», або сталих, закупівель. Фактично, «зелений офіс» узагальнює ключові поняття напряму де матеріалізації, поєднуючи мотиваційні аспекти усіх ланок підприємства.

Стратегічною частиною «зеленого офісу» вважаємо добровільне екологічне звітування та декларування. Окрім внутрішніх функцій таких звітів, необхідних для вибору подальших стратегій зменшення впливу на природне середовище, зовнішня функція полягає у популяризації компанії i, таким чином, підвищення iі конкурентоспроможності. Відкриття компаніями екологічної інформації є стартовим кроком до функціонування якісної системи екологічного страхування i надання компаніям необхідного рівня послуг за адекватну ціну і з врахуванням їх здатності ефективно керувати екологічними ризиками. Надання добровільних екологічних звітів є лицевою стороною системи взаємодії промисловості, державної влади та населення 3 досягненням між ними мотиваційного консенсусу на умовах прозорості. 
На даний час оприлюднення інформації щодо не фінансових аспектів діяльності підприємств практично повністю знаходиться у полі діяльності внутрішнього маркетингу. Вітчизняні компанії відкривають аспекти щодо умов праці, співпраці з місцевими громадами, стосовно благодійництва і збереження та відтворення довкілля у тих пропорціях, які вважають за потрібне, i які найкращим чином впливають на репутаційні аспекти представлення підприємств. Пріоритетність оприлюднення екологічних звітів є перспективою у подальшому розвитку зеленої економіки. Екологічний звіт, що відповідає критерію повноти наданої інформації, містить дані про екологічні аспекти діяльності підприємства, екологічну політику, іiі ефективність та дієвість, а також реалізовані екологічні проекти та досягнення. Пункт про відповідність діяльності підприємства вимогам природоохоронного законодавства є почасти формальним.

Окремі кроки у напрямку розв’язання екологічних проблем на локальному рівні є малоефективними, тому Стратегія до 2030 року включає формування загальносуспільних екологічних цінностей та запровадження в Україні системи зелених закупівель [1].

Послідовна екологізація економіки 3 урахуванням сталості може функціонувати на кількох рівнях:

1. На макрорівні та галузевому рівні може ініціюватися зміна експортної політики та структурні перебудови частин економічного механізму природокористування.

2. На рівні галузей та підприємств ініціюють розвиток ресурсозберігаючих технологій та проводять прямі природоохоронні заходи (прикладом $є$ регіональні програми розвитку, які включають регулювання функціонування очисних споруд, питання їх створення та безпечної експлуатації). Найбільш доцільним для сучасних промислових підприємств України є створення на підприємствах замкнених циклів (повторне використання ресурсів).

В сучасних реаліях електроенергія 3 відновлюваних джерел може забезпечувати окупність крупних та середніх проектів приватних домогосподарств. Економічне регулювання ощадливого споживання ресурсів в енергетичній сфері напряму пов'язане із законодавством щодо «зеленого» тарифу. Отримання енергії з традиційних джерел не відповідає принципам екологічної економіки, тому вартує суспільству погіршення екологічної ситуації, пов'язаної 3 надмірними витратами водних ресурсів, тим часом зростає й вартість витрат для підприємств, пов'язана ремонтними та аварійновідновлюваними роботами, затребуваними в енергетичних галузях [5]. 
Для стимулювання використання альтернативних джерел енергії був введений спеціальний тариф, за яким визначають ціну закупівлі енергії, виробленої 3 альтернативних джерел енергії. Даний тариф встановлює Національна комісія, що здійснює державне регулювання у сферах енергетики та комунальних послуг. Втім, питання регулювання «зеленого» тарифу лежить цілком у політичному векторі. Інтенсивні зміни у законодавстві викликають побоювання інвесторів стосовно компенсації тарифу, на який спираються інвестиційні плани підприємств. Щоквартально відбувається індексація тарифу згідно валютного курсу (курсу євро). Згідно поточного законодавства, «зелені» тарифи діятимуть до 2029 року, але поступово будуть зменшуватися. Світові тренди продовжують констатувати посилювану тенденцію до зниження цін на енергію, що виробляється 3 відновлюваних джерел, що примножує вигоди, враховуючи зменшені нецінові суспільні витрати на підтримання екологічної безпеки [6]. У 2019 році зеленого тарифу були позбавлені наземні електростанції (для дахів та фасадів ситуація залишалася незмінною), втім, у тому ж році тариф було законодавчо повернено в економіку, хоча компенсації згідно тарифам мають схильність до несвоєчасності здійснення.

Висновки. Врахування актуальних суспільних потреб, мотивацій підприємництва та довгострокових державних перспектив приводить до акцентуалізації напрямку зеленого офісу (як зразкового явища) та екологізації економіки загалом (як складного процесу, що полягає у поєднанні економічного розвитку та екологічної перспективи), а також до розгляду проблеми зеленого тарифу, що, водночас, потрапляє у коло політичних питань.

Екологізація економіки 3 врахуванням цілі досягнення іiі сталості відбувається на макрорівні та на галузевому рівні. Що стосується енергетичного сектору, електроенергія 3 відновлюваних джерел дешевшає, i може забезпечувати окупність крупних та середніх проектів приватних домогосподарств. Зауважимо, що регіональні державні енергетичні підприємства наразі не встигають сплачувати малим сонячним електростанціям «зелений тариф».

\section{Jimepamypa:}

1. Про Основні засади (стратегію) державної екологічної політики України на період до 2030 року. Закон України від 28 лютого 2019 року № 2697-VIII.

2. Про Основні засади (стратегію) державної екологічної політики України на період до 2020 року. Закон України від 21 грудня 2010 року 2818-VI.

3. Дубас Р. Г. Економіка природокористування. Навчальний посібник. - К.: «МП Леся», 2007. -448 c. 
4. Лісова Т. В. Правове забезпечення вимог екологічної безпеки при використанні земель промисловості. Режим доступу: http://dspace.nulau.edu.ua/bitstream/123456789/ 5572/ 1/Lisova_64\%E2\%80\%9367.pdf.

5. Зміни в законодавчому регулюванні альтернативної енергетики в Україні. Режим доступу: https://uz.ligazakon.ua/ua/magazine_article/EA012815.

6. Стимулювання використання відновлюваних джерел енергії та альтернативних видів палива. Режим доступу: http://saee.gov.ua/uk/business/preferentsii/derzh-pidtrymka/podatkovi-tamytni-pilgy7.

\section{References:}

1. Zakon Ukrainy "Pro osnovni zasady (strategiyu) derjavnoyi ekologichnoyi polityky Ukrayiny na period do 2030 roku” : vid 28 liutoho 2019 roku № 2697-VIII [Law of Ukraine "About the Basic principles (strategy) of the state ecological policy of Ukraine for the period till 2030" from February 28, 2019, № 2997-VIII]. (n.d.). zakon.rada.gov.ua. Retrieved from https://zakon.rada.gov.ua/laws/show/2697-19\#Text [in Ukrainian].

2. Zakon Ukrainy "Pro osnovni zasady (strategiyu) derjavnoyi ekologichnoyi polityky Ukrayiny na period do 2020 roku" : vid 21 grudnia 2010 roku № 2818-VI [Law of Ukraine "About the Basic principles (strategy) of the state ecological policy of Ukraine for the period till 2020" from December 21, 2010, № 2818-VI]. (n.d.). zakon.rada.gov.ua. Retrieved from https://zakon.rada.gov.ua/laws/show/2818-17\#Text [in Ukrainian].

3. Dubas, R.H. (2007). Ekonomika pryrodokorystuvannia [Economics of nature management]. Kyiv: «MP Lesia» [in Ukrainian].

4. Lisova, T.V. (2014). Pravove zabezpechennia vymoh ekolohichnoi bezpeky pry vykorystanni zemel promyslovosti [Legal provision of environmental safety requirements for the use of industrial lands]. Derzhava i pravo v umovakh hlobalizatsii: realii ta perspektyvy - State and law in the context of globalization: realities and prospects : Materials of international scientific-practical conference. (pp. 64-67). Dnipropetrovsk. http://dspace.nulau.edu.ua/bitstream/123456789/5572/1/Lisova_64\%E2\%80\%9367.pdf [in Ukrainian].

5. Karhova, V., Shvydenko, D. (2019). Zminy v zakonodavchomu rehuliuvanni alternatyvnoi enerhetyky $\mathrm{v}$ Ukraini [Changes in the legal regulation of alternative energy in Ukraine]. uz.ligazakon.ua. Retrieved from https://uz.ligazakon.ua/ua/magazine_article/EA012815 [in Ukrainian].

6. Pilhy ta stymuliuvannia. 3. Stymuliuvannia vykorystannia vidnovliuvanykh dzherel enerhii ta alternatyvnykh vydiv palyva [Benefits and incentives. 3. Stimulating the use of renewable energy sources and alternative fuels]. (n.d.). saee.gov.ua. Retrieved from http://saee.gov.ua/uk/business/preferentsii/derzh-pidtrymka/podatkovi-ta-mytni-pilgy7 [in Ukrainian]. 